УДК 343.352.4:94

DOI https: / / doi.org/10.32837/yuv.v0i1.2082

\author{
В. Плекан, \\ кандидат юридичних наук, \\ прокурор відділу
Генеральної інспекції Офісу Генерального прокурора
}

\title{
ІСТОРИКО-ПРАВОВІ ПЕРЕДУМОВИ ВИНИКНЕННЯ КОРУПЦІЇ В ПРАВООХОРОННИХ ОРГАНАХ УКРАЇ̈И
}

Постановка проблеми. Становлення України як демократичної держави неможливе без зниження рівня корупції в державі, в тому числі в правоохоронних органах, одним із завдань яких $є$ забезпечення дієвої боротьби із цим негативним явищем. У засобах масової інформації досить часто публікуються новини щодо корупційних скандалів за участю посадових осіб поліції, Служби безпеки України, митниці, прокуратури. Окрім цього, корупційні злочини, що вчиняються працівниками правоохоронних органів, негативно впливають на стан законності в державі в цілому, породжують недовіру до цих органів. Водночас теперішній стан корумпованості правоохоронних органів не виник одномоментно, а цьому передували ряд історичних подій, що мали місце в розвитку України.

Метою наукової статті $€$ теоретичний аналіз і узагальнення історичних передумов, які сприяли виникненню корупції у правоохоронних органах, а також дослідження ефективності правових актів, спрямованих на подолання корупційних явищ, що виникали на території українських земель в різні історичні періоди.

Стан дослідження. Окремим аспектам виникнення та генезису корупції в правоохоронних органах, а також розвитку законодавства, спрямованого на подолання корупції, присвячені роботи науковців
Бабікова О.П., Вергуна С.I., Говорова І.В., Гусєвої В.П., Скіпського Г.А., Серова Д.О., Сопілко І.М., Сторчилової Н.В., Павленка С.О., Цитряка В.Я., Утвенко В.В., Яковенка С.Б. та інших.

Виклад основного матеріалу. Виникненню будь-якого соціального явища у тому числі корупції передує значна кількість історичних чинників, що зазвичай взаємопов'язані між собою та створюють підгрунтя для подальшого їх розвитку.

Перші свідчення про магістратів, які виконували правоохоронні функції, та правові норми, якими регулювалась їх діяльність на півдні сучасної України, належать до другої половини I тисячоліття до нашої ери. Спочатку це були окремі магістратури античних полісів Північного Причорномор'я, пізніше - посадові особи кримських колоній Візантії та Генуї. У містах-державах Північного Причорномор'я за афінським зразком були засновані колегії номофілаків з 5-7 осіб. Їхня діяльність значною мірою спрямовувалась саме на попередження та викорінення проявів корупції, небезпеку якої розуміли вже тоді [1].

Кінець IX - початок X століття можна назвати періодом становлення державності у Київській Русі, що на той час була союзом племінних князівств, у яких формування вищих органів влади відбувалося шляхом впровадження десяткової системи управління без виокремлення 
центрального управління від місцевого. В основі цієї системи лежав принцип військової організації влади, коли управління окремими територіальними одиницями здійснювали начальники військових підрозділів тисяцькі, соцькі і десяцькі. Тисяцький був начальником найбільшого військового гарнізону, який базувався у великих і важливих містах, а соцькі командували окремими, меншими його частинами (дружинами). Соцькі та десяцькі здійснювали військову, адміністративну, фіскальну, судову і поліцейську владу на місцях.

Тіун, як за часів Київської Русі називали чиновника, не отримував зарплату з казни, а натомість за ним закріплювалось кілька міст та сіл, які його у буквальному сенсі «кормили». Тіун збирав для князя податки, а частину грошей залишав собі. При цьому воєводи та намісники зловживали наданою їм владою, повсюди вимагали від жителів винагороду понад норму та збагачувались їхнім коштом, що пояснювалося відсутністю будь-яких санкцій за невиконання цих положень законодавства. Ймовірніше, на думку Ю.М.Походзіло, щоб отримати «кормління», треба було дати хабар дяку, що розподіляє його [2].

У результаті земської реформи 1555-1556 років система кормлінь була ліквідована згідно з указом про скасування кормлінь, який було впроваджено, однак не відразу і не скрізь: джерела продовжують згадувати про кормління протягом другої половини XVI століття.

Слід погодитись із Д.О. Серовим та іншими науковцями 3 приводу того, що першим напівлегальним виявом хабарництва було «кормління» - інститут, при якому чиновництво «кормилось» (утримувалось) коштом населення відповідної території. Згодом такий стан речей почав зазнавати певних змін у зв'язку із централізацією держави та реформуванням управлінської системи у світлі ії професіоналізації та пере- ходу від тимчасової служби до постійної, коли утримання службовців відбувалось за рахунок центру з державної казни. Склалася своєрідна ситуація, коли поряд з державним утриманням чиновників продовжує існувати (але вже як додаткові доходи) і приватна винагорода - «посул». Проте така винагорода продовжувала вважатися соціально прийнятною і виправдовувалася столітніми традиціями утримання чиновників за рахунок поборів від населення [3].

Щодо джерел права Київської Русі в XI-XIV столітті, то основним була «Руська Правда», норми якої передбачали відповідальність за злочини. Так, за скоєний злочин у Київській Русі можна було просто відкупитись, а сума штрафу залежала від соціального статусу жертви: вбивство чиновника «коштувало» дорожче, ніж простого смертного. Проте родичі жертви мали законне право самостійно поквитатись із кривдником за принципом «око за око, зуб за зуб». А суддям взятку давали не для вирішення справи на власну користь, а просто для того, щоб суддя почав і1і розгляд [4].

Таким чином, у період становлення та розвитку Київської Русі виникає система «кормлінь» тіунів (чиновників), яка й стає основою зародження та формування корупційних явищ впродовж подальших історичних періодів розвитку української державності. Норми «Руської Правди» не передбачали відповідальності за будь-які прояви хабарництва з боку тіунів, оскільки таке поняття взагалі не існувало, а також закріпили на законодавчому рівні традицію «відкуплення» від покарання за вчинений злочин. Наведені суспільно-політичні обставини були соціально-політичними передумовами для виникнення та подальшого генезису корупції серед чиновників, що здійснювали правоохоронну діяльність на території українських земель. 


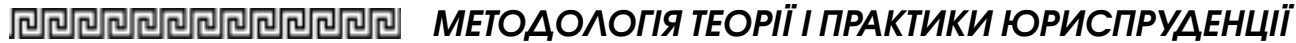

На західноукраїнських землях (Галицька, Львівська, Перемишльська, Саноцько-Холмська, Подільська, Белзька), які були приєднані до Польщі з 1433 року, було поширено польське земське право. Серед збірників польського права виділяють Вислоцький статут 1347 року, Вартський статут 1420-1423 років, Збірник польських законів 1782 року. Ці правові пам'ятки також не передбачали відповідальності за хабарництво чиновників.

Після входження українських земель до складу Великого князівства Литовського у XIV столітті, а згодом до Речі Посполитої у 1569 році, на ї території поширюється дія Литовських Статутів - основних законодавчих документів Великого князівства Литовського. Чимало ідей цих статутів були запозичені з правових норм і традицій Київської Русі, зокрема 3 «Руської правди». Так, у королівських судах Речі Посполитої чиновники могли уникнути покарання за умови наявності покровителя та статків. Тогочасний історик Ш. Старовольський так описував правосуддя Речі Посполитої: «У судах у нас завелися нечувані побори, підкупи; наші війти, лавники, бурмистри - всі продажні, а про донощиків, які підводять невинних людей в біду, і говорити нема чого. Спіймають багатого, заплутають і засадять до тюрми, та й тягнуть 3 нього подарунки і хабарі» [5].

Аналізуючи законодавство, що діяло на території Речі Посполитої, потрібно зазначити, що у ньому не передбачалось відповідальності за хабарництво як злочин, а прояви корупції мали повсякденний характер.

3 утворенням у XVI-XVII століттях Запорізької Січі та введенням в Україні полкового устрою вся охоронна та розшукова діяльність зосереджується в руках отаманів і гетьманів, а кримінальне судочинство здійснюють полкові судді, писарі за дорученнями полковників і гетьма- нів, тобто не було поділу влади на адміністративну та судову. У системі козацького управління та судочинства найвищою ланкою був гетьман, який часто залучав Раду генеральної старшини для розслідування злочинів на місці; а для розслідування обставин справ і проведення виїзних засідань - сотенно-полкову старшину, представників міністрів і ратуш. Його посланці брали участь у роботі полкових слідчих комісій і засіданні судів, зокрема, коли слухалися важливі кримінальні справи [6]. Право, закони та суд Війська Запорізького у цей період, з одного боку, були демократичними, а 3 іншого - вищі стани приймали такі правові акти, які часто робили старшину та шляхту непідсудними - мали виражений становий характер [7].

Так, козацьке право по суті своїй було звичаєвим та письмових джерел не мало [8]. У 1728 році російська імператриця Єлизавета Петрівна видала указ про створення спеціальної кодифікаційної комісії, що повинна була створити нове кодифіковане українське законодавство, яке б узгоджувалося з російським. Після 15-річної роботи у 1743 році було презентовано проєкт нового кодексу під назвою «Права, за якими судиться малоросійський народ», який складався з 30 глав, що містили 532 артикули і 1607 пунктів та передбачали норми кримінального, цивільного, адміністративного, торгового і процесуального права. На той час кодекс увібрав у себе найкращі досягнення правової думки, але так і не набув чинності [9].

Окрім, цього «Права, за якими судиться малоросійський народ» 1743 року передбачали значну кількість антикорупційних норм, однак активний корупційний підкуп криміналізовано не було [10].

Ураховуючи недосконалість чинної на той час системи законодавства та пріоритет звичаєвого права 3 елементами системи «кормлінь», 
на території Запорізької Січі непоодинокими були випадки корупції серед вищих ланок чиновників, які були наділені правоохоронними функціями.

Так, упродовж 1750-1755 років розслідувалася справа стародубського городового отамана Федора Яскевича, який здійснював свавільні арешти, а також на свій розсуд випускав 3 в'язниці арештантів, використовуючи їх для робіт у власному господарстві. Крім цього, Яскевич бив міщан та козаків, стягував з них незаконні побори. Результатом слідства було звільнення Федора Яскевича з посади городового отамана. У 1759 році були оштрафовані члени миргородського полкового суду за несправедливе рішення у судових справах. У жовтні 1762 році був звільнений з посади смілянського сотенного писаря (Лубенський полк) Іван Сербин за фальсифікацію присяжних листів [11].

3 розпадом наприкінці XVIII століття Речі Посполитої українські землі увійшли до складу Російської імперії, а західноукраїнські землі - до складу Австро-Угорщини. Така ситуація спричинила заміну польського законодавства австрійським. 3 кінця XVIII століття Кримінальний кодекс Австрії 1787 року було введено в дію на всій території цих українських земель. У 1852 році було введено в дію новий Кримінальний кодекс, який поширювався на Галичину та Буковину. На Закарпатті з 1879 році почав діяти Угорський кримінальний кодекс [12].

На території українських земель, які перебували в Російській імперії, правоохоронна діяльність та боротьба 3 корупцією здійснювалась відповідно до російського законодавства.

У 1497 році був прийнятий Судебник, за яким стало вершитись правосуддя і який вперше заборонив отримання матеріальних цінностей при веденні судових справ і розгляді скарг чиновниками. Так, стаття 1 Судебника передбачала, що «суд здійснюється боярами і окольничими в присутності дяків. Суддям забороняється брати за звершення суду і клопотань хабаря, а також вирішувати справу несправедливо 3 мотивів помсти чи дружби зі стороною». При всій своїй прогресивності стосовно заборони посулів (як правило, у сфері судочинства) поза увагою було залишено низку принципових обставин. Насамперед це відсутність чіткої санкції за одержання посулу, недосконала розробленість суб'єктного складу його одержання та форм вияву, що частково було врегульовано Судебником 1550 року, де вперше знайшло відображення розмежування підкупу на мздоїмзство та лихоїмство [13].

Соборне уложення 1649 року (далі - Уложення 1649 року) частково розвинуло положення про відповідальність за одержання хабаря, встановивши в окремих статтях відповідальність за кваліфіковане отримання хабаря. Однак в деяких статтях законодавець відступив від досягнутих положень, переставши переслідувати отримання обіцянок, і більшою мірою піклувався про правосуддя в судах. Однак, Уложення 1649 року не містило загальної статті, яка б забороняла отримання хабаря, за винятком глави X «Про суд», де передбачалась відповідальність за виправдання винного і засудження невинного суддями за хабар. Разом із цим в Уложенні 1649 року, на відміну від Уложення 1550 року, суб'єктами злочину могли бути судді, дяки, піддячі, і встановлювалися більш певні санкції за вчинення цієї групи злочинів [14]. Інші дослідники, зокрема П.В. Номоков, критично оцінюють цей правовий акт, оскільки він не розширив, а навпаки, звузив сферу правового регулювання вказаного діяння [15].

3 огляду на поширеність хабарництва Указом від 23 серпня 1713 року Петро I ввів поряд 3 отриманням хабаря кримінальну відповідальність за давання хабаря, що передбачала смертну кару. Ефективність вжитих заходів виявилася недостатньою, 


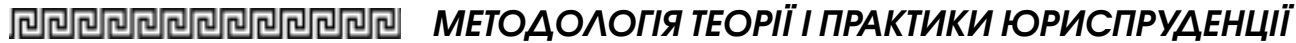

і 24 грудня 1714 року був виданий новий Указ, який ввів кримінальну відповідальність за пособництво у скоєнні корисливого зловживання на службі і за недонесення про скоєння цих злочинів.

Також Петром I були створені правоохоронні органи, що забезпечували контроль за діяльністю посадових осіб, - фіскали, які теж не вирізнялись безкорисливістю. Так, ярославський провінц-фіскал Попцов в період знаходження на посаді отримував хабарі від підпорядкованих фіскалів та інших осіб, за що був засуджений до смертної кари і страчений [16]. На початку 1722 року поряд з фіскалами, а потім і для їх заміни було створено новий орган нагляду - прокуратуру, в якій фіскали виконували роль нижчих агентів [17].

Наступним етапом у розвитку антикорупційного законодавства Російської імперії було запровадження Уложення про покарання кримінальних та виправних від 1885 року (далі - Уложення 1885 року), яке, не згадуючи терміна «корупція», формулювало велику кількість складів злочинів, що передбачали відповідальність за корисливі та інші зловживання службовими обов'язками чиновників та інших осіб, «які перебувають на службі державній чи громадській» .

У статті 401 Уложення 1885 року встановлювалася кримінальна відповідальність за «хабарництво», покарання, за вчинення якого виражалося в грошовому стягненні, вдвічі більшому проти ціни прийнятого. У даній статті вказувалися дві форми отримання хабаря: хабар-подяка i хабар-підкуп. За підкуп посадова особа органів державної влади i управління, окрім грошового стягнення, піддавалася ще й звільненню із займаної посади, а в разі діяльного каяття посадової особи у скоєному злочині, пов'язаному 3 отриманням непередбаченої законом винагороди, ii могло бути за рішенням суду піддано більш м’якому покаранню.
Разом з тим вчені Г.А. Скіпський, C.M. Міхеєва зазначають, що принципи подвійних стандартів спрацьовували у випадку визначення ступеня покарання за вимагання хабаря. Найбільший ризик понести покарання мали лише нижчі поліцейські чини (городові, околотичні чи урядники). Можливість уникнути покарання була значно вища у керівників середнього рівня (поліцмейстерів, приставів та їх помічників). Абсолютно безкарно себе почували представники вищого начальства [18].

Хабарництво серед правоохоронців в період Російської імперії було дійсно серйозною проблемою, на яку неодноразово зверталась увага керівництву держави. Здебільшого це було обумовлено низьким рівнем їх матеріального забезпечення.

Зокрема, у 1831 році Міністр внутрішніх справ Російської імперії A. Закревський, відвідавши особисто губернії європейської частини Російської імперії і побачивши місцеву адміністрацію та поліцію в невтішному стані, надав імператору Миколі I доповідну, в якій вказував: «Не можна без співчуття дивитися на цих людей, що сидять в присутственних місцях перед зерцалом законів у дранті, з печаткою злиднів і зневіри на обличчях. Треба уявити ту бідність, в котрій служать вони, будучи чоловіками й батьками сімейств, без міцного одягу і взуття, ймовірно і без їжі. Як можна очікувати старанності від людини, яка вирішила служити за 5 і навіть за 1 рубль (асигнаціями) в місяць. Як можна тішити себе надією утримати руку нужденної від потреби людини, прийняти пропонованих в таємниці і вимагають від прохача грошей. Це і є корінь хабарництва і розпусти чиновників» [19].

Незважаючи на це, в цілях зниження дефіциту бюджету в період з 1859 по 1910 роки розміри грошового утримання правоохоронних органів в Російській імперії не підвищувались, а навіть були значно нижче, ніж 
в інших чиновників, що своєю чергою зумовило інтенсивний ріст корупції серед них.

До прикладу, I.В. Говоров із посиланням на спогади жителів Російської імперії так описує народну характеристику працівників правоохоронних органів: «Поліцейські чини були хабарниками...за хабар можна було «замазати» будь-яке правопорушення і навіть злочин», «Поліція не користувалась в народі повагою..., ii не поважали, а просто зневажали. Під час свят хабарі набували узаконеного виду. Вважалось обов'язковим, щоб домовласники, торговці, підприємці відправляли всім начальникам в поліцейській дільниці до Нового року та свят привітання 3 «додатком». Околотичним, квартальним и городовим «привітання» вручались прямо в руки, так як за привітаннями вони з' являлись самі» [20].

За даними радянського історика П.А. Зайончковського, у губерніях Правобережної України всі поміщики регулярно платили хабарі чинам поліціï. В усіх значних маєтностях існували щорічні оклади для поліцейських чиновників із різноманітних видів продовольства. Від цукрових заводів та «питейних» відкупників для поліцейських посилали цукор, горілку й гроші [21].

В.Б. Молчанов зазначає, що корупція мала місце і серед працівників карного розшуку. Так, київський поліцмейстер В. Цихоцький на початку XX століття особливо вирізнявся хабарництвом, порушенням штатного режиму, привласненням значних сум грошей [22].

Цікава ситуація виникла у Київському охоронному відділенні, коли у 1911 році при перевірці особового складу таємних агентів, причиною якої було вбивство прем'єр-міністра Російської імперії П. Столипіна, виявилося, що більшість таємних агентів на утримання яких начальник Київського охоронного відділення М. Кулябко виділив 30 тисяч рублів була фіктивною, існувала виключно на папері [23].

Також, як зазначає C.I. Вергун, корупція була однією із проблем у діяльності жандармських поліційних управлінь залізниць України, що перешкоджала іiі ефективному функціонуванню та охопила всю вертикаль їхніх підрозділів та посадовців: від унтерофіцерів до начальників відділів та управлінь залізниць. Форми корупції були різноманітними, але здебільшого пов'язані із використанням свого посадового становища (жандарми спочатку затримували підозрілу особу, потім погрожували протоколом та ув'язненням, а в разі згоди за кругленьку суму «дарували свободу» затриманому, причому це могли бути як адміністративні правопорушники, так і політичні). Попри усі намагання влади подолати корупцію різними реорганізаціями поліційно-жандармської системи та застосуванням адміністративних заходів, позитивного результату досягти так і не вдалося [24].

Таким чином, заходи кримінальноправового попередження, направлені на вдосконалення законодавства i посилення санкцій за вчинення хабарництва, не дали належного ефекту i не дозволили вирішити в цілому цю проблему. Окрім цього, корупція серед працівників правоохоронних органів набирала більш системних та удосконалених форм, пронизуючи всю правоохоронну систему, а відповідальність не застосовувалась до вищої ланки. Однією з основних причин такої ситуації був недостатній рівень матеріального забезпечення працівників правоохоронних органів.

3 утворенням Союзу Радянських Соціалістичних Республік (далі СРСР) розпочався новий етап подолання хабарництва у чиновницькому апараті. Так, Декрет Ради народних комісарів (далі - РНК) «Про хабарництво» від 08 травня 1918 року став першим правовим актом, що передбачав

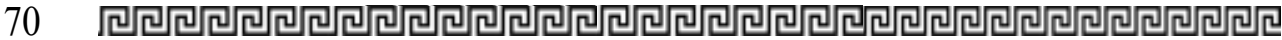




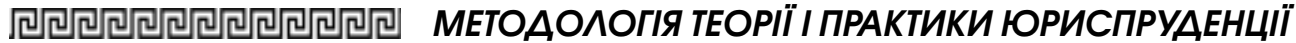

кримінальну відповідальність за хабарництво, а замах на отримання або дачу хабаря прирівнювався до злочину [25].

26 квітня 1919 року Радою Народних Комісарів Української Радянської Соціалістичної Республіки (далі УРСР) прийнято Декрет «Про хабарництво та незаконні побори», де передбачались більш суворі покарання за хабарництво, а у липні 1921 року РНK України за підписом голови Х. Раковського видає постанову «Про заходи боротьби 3 посадовими злочинами», у якій пропонується застосувати за хабарництво покарання аж до найвищої міри покарання, тобто до смертної кари. Надалі 16 серпня 1921 року РНК було видано новий Декрет «Про боротьбу з хабарництвом», який уточнив склад одержання хабаря [26].

У 1922 році був прийнятий Кримінальний кодекс УРСР (далі Кодекс), який був першим кодифікованим актом, що систематизував норми радянського кримінального права, у якому була передбачена відповідальність за одержання службовою особою хабаря. Ці ж положення перейшли до Кодексу 1927 року. Статтею 117 встановлювалась відповідальність за одержання службовою особою особисто або через посередників у будь-якому виді хабаря за виконання чи невиконання в інтересах особи будь-якої дії, яку службова особа могла і повинна була вчинити виключно внаслідок свого службового становища [27].

Як правильно зазначає В.П. Гусєва, дослідження поширення у 20-х роках $\mathrm{XX}$ століття явища, яке на сьогодні іменується корупцією, у СРСР $€$ доволі важким завданням, оскільки вся країна була охоплена червоним терором, численними репресіями, порушенням прав людини та зневаги до людини як живої істоти. У зв'язку із цим, в архівних матеріалах $€$ нечисленні факти вчинення корупційних правопорушень, зокрема й учасниками кримінального процесу [28].
Так, у 1926 році у залі Київського інституту народної освіти відбувся судовий розгляд щодо корупційних зловживань в діях київських міліціонерів, який набув значного суспільного резонансу та детально висвітлювався в засобах масової інформації. Водночас серед підсудних не було начальника губернської та міської міліції $\Phi$. Коваленко, але був його помічник, начальники постачання та промислової поліції, а також майже всі начальники та рядові співробітники.

У ході слідства була встановлена наступна корупційна схема. Так, начальники райвідділів систематично платили відкати за хороше ставлення по службі та звітність по розкриттю злочинів, надалі вказану схему застосовували дільничні, які своєю чергою отримували хабарі від підприємців та торговців на своїх дільницях. Будьякі матеріальні потреби міліцейського керівництва задовольнялись коштом підприємців, а у випадку незгоди останніх, до них застосовувалися засоби тиску на торгівлю. Пособниками в отриманні хабарів виступали дружини керівників міліції. До прикладу, начальник промислової міліції спільно 3 інкасатором перерозподіляли суми коштів, призначені для охорони різних підприємств, а начальник постачання під час закупівлі товарів і матеріалів для міліції платив приватним підприємцям кошти за завищеними цінами, отримуючи від них відкати. Своєю чергою, начальник оперативно-розшукової частини отримував хабарі від родичів арештованих злочинців за різні переваги [29].

Також цікавою є праця адвоката M.В. Палібіна, який проводив свою діяльність у 20-60-х роках XX століття та викривав корумпованість радянської судової і правоохоронної систем. Так він описує перевірку прокурором колгоспу: «Приїжджає прокурор, колишній співробітник НКВД в колгосп, вірогідно знаючи, що в колгоспі є недоліки. Оскільки він $з$ дороги голодний, залежно від 
сезону йому подають яблука і мед, чи яєшню, чи смажену баранину. Після цього він вимагає надати йому статистичні і бухгалтерські дані, в яких він заздалегідь знайшов недоліки. Після цього, він запитує скільки коштує м'ясо, на що йому пропонують ціну нижчу ринкової» [30].

Під час «хрущовської відлиги» стали порушуватися кримінальні справи, які показали, що корумпованими $€$ не тільки чиновники, а й правоохоронна система - міліція, прокуратура, суди. На початку 1950-х років правоохоронні органи УРСР розкрили злочинну групу, яка займалася великими розкраданнями палива в Києві [31].

Подальше збільшення кримінальної репресії відносно суб'єктів корупції знизило загальний рівень корупційних проявів, але не знищило їх. Партійна «кругова порука», кумівство та звичайне користолюбство підживлювали існування різних корупційних схем. Перший секретар ЦК КП України М.С. Хрущов наполіг на тому, щоб дії розкрадачів суд кваліфікував не відповідно до Указу Президіі ВР СРСР від 04.06.1947 року «Про кримінальну відповідальність за розкрадання державного й громадського майна», а як «економічну контрреволюцію, а згодом до Кримінального кодексу повернули смертну кару за отримання хабаря. Однак застосування найвищої міри покарання мало зворотний ефект, оскільки викривачі боялись повідомляти про злочин, що мав наслідком смерть хабарника [32].

Утім, поступова лібералізація державного управління послабила кримінальну репресію хабарників. I наступний етап у розвитку правової бази запобігання та боротьби з корупцією забезпечив Кримінальний кодекс УРСР 1960 року. Відповідальність за одержання хабаря була передбачена статтею 168 KK України. Покарання за хабарництво було встановлене у вигляді позбавлення волі на строк від п'яти до десяти років 3 конфіс- кацією майна і позбавленням права обіймати певні посади чи займатися певною діяльністю на строк до п'яти років [33].

Найбільших масштабів корупція в СРСР набула в роки правління Л.І. Брежнєва. Вона стала невіддільною частиною й умовою функціонування управлінського апарату, тіньової економіки, соціального розшарування суспільства й однією із причин деградації економічного й політичного життя.

Партійна номенклатура користувалася своїм становищем і нерідко перевищувала свої повноваження. Цей процес тривав до 1982 року, поки Генеральним секретарем не став Ю.А. Андропов. Він керував країною менше півтора роки, але в боротьбі 3 корупцією досяг більш істотних результатів, ніж М.С. Хрущов і Л.І. Брежнєв разом узяті, хоча вони i не ставили антикорупційну діяльність на меті. Головними методами боротьби Ю.А. Андропова були виявлення, припинення та розкриття злочинів, а також «чистка» кадрів. Водночас набули розголосу гучні корупційні скандали, такі як «Азербайджанська справа», пов'язана із продажем посад у державних органах, в тому числі в правоохоронних структурах, «Справа Щолокова» щодо виявлення корупції в діях колишнього Міністра внутрішніх справ СРСР та його підлеглих, «Бавовняна справа», в ході розслідування якої було виявлено значну суму грошових коштів та матеріальних цінностей в начальника ВБРСВ МВС Бухарського облвиконкому Узбецької PCP [34].

Після проголошення у 1991 році незалежності країнами-республіками колишнього СРСР корупційні злочини серед чиновників набули неймовірних масштабів, боротьба 3 якими триває й до сьогодні.

Висновки. Таким чином, проаналізувавши майже тисячолітню історію становлення та розвитку пра-

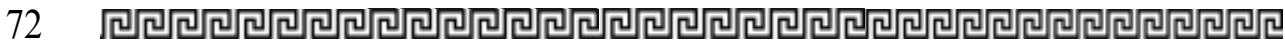




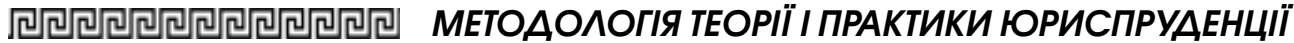

воохоронної системи на територіях сучасної України, слід констатувати, що корупція була і залишається невіддільним елементом повсякденного функціонування правоохоронних органів.

Історичний досвід вказує на те, що соціально-політичними передумовами виникнення корупції у правоохоронних органах було узаконення системи «кормлінь» на території Київської Русі в кінці IX - на початку $\mathrm{X}$ століття, прояви якої мають місце і в теперішній час, а також закріплення в «Руській Правді» правового механізму «відкуплення» за вчинений злочин.

Подальший перехід від натурального податку до оплати роботи чиновників грошима лише поглибив інтеграцію корупційних явищ $\mathrm{y}$ ï свідомість та повсякденну діяльність, а застосування в Козацькій державі звичаєвого права, успадкованого із часів Київської Русі, не змінило ставлення до «посулів» та інших матеріальних вигод як способу вирішення суспільних питань, що можна розцінювати як ментальні передумови виникнення корупції в правоохоронних органах.

У період перебування українських земель в Австро-Угорській та Російській імперіях відзначається тенденція до зростання рівня корупції серед правоохоронців, удосконалення ними форм та методів отримання незаконних матеріальних благ, що була зумовлена соціально-економічними чинниками, зокрема низьким рівнем матеріального забезпечення працівників правоохоронних органів, кризовими явищами в економіці цих держав.

До соціально-правових передумов виникнення корупції в правоохоронних органах слід віднести недостатній рівень правового забезпечення, спрямованого на подолання корупції, застосування принципу «подвійних стандартів» до покарання чиновників вищої та інших ланок, неврегульованість компетенції правоохоронних органів, «кругову поруку», приховування фактів корупціі як негативного явища.

Становлення України як демократичної держави неможливе без зниження рівня корупції в державі, у тому числі в правоохоронних органах, одним із завдань яких $є$ забезпечення дієвої боротьби із иим негативним явищем. У засобах масової інформаціі досить часто публікуються новини щодо корупційних скандалів за участю посадових осіб поліциї, Служби Безпеки Украӥни, митниці, прокуратури. Окрім цьього, корупційні злочини, щзо вчиняються працівниками правоохоронних органів, негативно впливають на стан законності держави в цілому, породжують недовіру до изих органів. Водночас mеперішній стан корумпованості правоохоронних органів не виник одномоментно, оскільки виникненню будь-якого соціального явища в тому числі корупції передуе значна кількість історичних чинників, які нерідко взаємопов'язані між собою та створюють підтрунтя для подальшого іх розвитку.

Метою дослідження у изій статті є виокремлення історичних передумов, які сприяли виникненню корупиіï в правоохоронних органах, а також дослідження дієвості правових актів, спрямованих на подолання корупційних явищ, щзо виникали на території українських земель в різні історичні періоди.

Автором досліджено історико-правові передумови для виникнення корупціï в правоохоронних органах України. Проаналізовано антикорупційне законодавство, що діяло на українських землях з часів Киїської Русі, у складі Великого князівства Литовського, Речі Посполитої, Австро-Угорської та Російської імперій, СРСР $i$ до моменту проголошення Україною Незалежності у 1991 році, з точки зору його ефективності, достатності 
та безпосередніх результатів впливу на стан $i$ рівень корупції. Упродовж кожного історичного періоду надано оцінку методам, спрямованим на подолання корупціiі, що впроваджувались на держаному рівні. Досліджено історично встановлені факти корупції, щз мали місие в діяльності правоохоронних органів на території українських земель. За результатами дослідження виокремлено ключові сочіально-правові, ментальні, сочіально-економічні та соціально-політичні передумови для виникнення та подальшого розвитку корупиії в правоохоронних органах України.

у статті автором досліджено історичні передумови для виникнення корупціi в правоохоронних органах України. Проаналізовано антикорупиійне законодавство, яке діяло з часів Київької Русі $i$ до проголошення Україною Незалежності у 1991 роциі. Досліджено факти корупціï, щзо мали місцее в діяльності правоохоронних органів на території українських земель. За результатами дослідження виокремлено ключові соціально-правові, ментальні, соціально-економічні, соціально-політичні передумови, які сприяли становленню та подальшому розвитку корупиї у правоохоронних органах України.

Ключові слова: корупція, правоохоронні органи України, корупційні правопорушення, передумови виникнення корупціі, історія корупції.

Plekan V. Historical and legal prerequisites for the occurrence of corruption in the law enforcement agencies of Ukraine

The establishment of Ukraine as a democratic state is impossible without reducing of the level of corruption in the state, including in law enforcement agencies, one of the tasks of which is to ensure an effective fight against this negative phenomenon. The media frequently publishing news concerning corruption scandals involving officials of the police, the Security Service of Ukraine, customs, and the Prosecutor's office. In addition corruption crimes committed by law enforcement officers affecting negatively on the rule of law in the state as a whole, creating distrust in these bodies. At the same time, the current state of law enforcement corruption has certainly not arisen at once, as a large number of historical factors that are often interconnected and create the basis for their further development precedes the emergence of any social phenomenon, including corruption.

The purpose of this article is to highlight the historical background that contributed to the emergence of corruption in law enforcement agencies, as well as to study the effectiveness of legal acts aimed at overcoming corruption in the Ukrainian lands through different historical periods. The author researches the historical and legal preconditions for the emergence of corruption in the law enforcement agencies of Ukraine. The anticorruption legislation that has been in force in the Ukrainian lands since the times of Kievan Rus, as part of the Grand Duchy of Lithuania, the Commonwealth, the Austro-Hungarian and Russian empires, the USSR and until Ukraine's declaration of independence in 1991 is analyzed in terms of its effectiveness, sufficiency and direct results of impact on the state and level of corruption. During each historical period author gives an assessment to the methods implemented at the state level for combating corruption.

The facts of corruption that took place in the activities of law enforcement agencies on the territory of Ukrainian lands are researched. According to the results of the research, the key socio-legal, mental, socio-economic, socio-political preconditions that contributed to the 


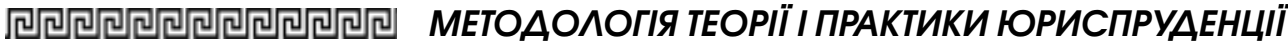

formation and further development of corruption in the law enforcement agencies of Ukraine were identified.

Key words: corruption, law enforcement agencies of Ukraine, corruption offenses, preconditions for corruption, history of corruption.

\section{Література}

1. Гавриленко О.A. Номофілактики античних полісів та синдики генуезьких колоній у Північному Причорномор'ї: історико-компаративне дослідження. Вісник Харківського національного університету внутрішніх справ. Харків, 2010. № 1 (48). C. 37-44.

2. Походзіло Ю.М. Становлення податкової функиії держави на українських землях у часи Київської Русі та феодальної роздробленості XII-XIV cm. Право та інноващії. Харків, 2017. № 4(20). C. 69-74.

3. Серов Д.О. Противодействие взяточничеству в России: опьт Петра I (законодательные, правоприменительные и организационные аспекты). Уголовное право. Москва, 2004. № 4. С. 118-120.

4. Правда Руська. Тексти на основі 7 списків та 5 редакцій / за ред. проф. С. Юиков. Київ : ВУАН, 1935. C. 137-144.

5. Szymon Starowolski. Lament Utrapiony Matki Korony Polskiej. URL: https:// https: / / books.google.com.ua / books?id=jm1b $A A A A Q A A J \&$ printsec $=$ frontcover $\& h l=u k \&$ sour $c e=g b s \_g e \_s u m m a r y \_r \& c a d=0 \# v=$ onepage $\&$ $q \& f=$ false (дата звернення: 24.01.2021).

6. Стеиюк Б. Органи кримінального судочинства Гетьманщини. Підприємниитво, господарство і право. Київ, 2005. № 11. C. 82-85.

7. Павленко С.О. Основи боротьби з хабарництвом: історичний аспект. Науковий вісник Національної академії внуmpiшнiх справ. Київ, 2013. № 2. С. 373-382.

8. Наріжний С. Судівництво і кари на Запорожжі / ред. С. Наріжний. Прага, 1939. $30 \mathrm{c}$

9. Права, за якими судиться малоросійський народ. 1743 / відn. ред. К.А. Вислобоков. Інститут держави $i$ права імені В.М. Корещького, НАН Украіни. Київ, 1997. 549 с.

10. Бабіков О.П. Антикорупиійні норми козащького права. Підприємниитво, господарство і право. Київ, 2018. № 5. C. 219-222.
11. Утвенко В.В. Зловживання службовим становищем в України в роки гетьманування K. Розумовського та антикорупиійні заходи гетьманського уряду. Історико-політичні студіі. Серія: Історичні науки : зб. наук. пр. / М-во освіти і науки України, ДВНЗ "Київ. нац. екон. ун-т ім. Вадима Гетьмана», Iн-m історії укр. сусп-ва ; редкол.: І. Д. Дудко (голова) [та ін.]. Київ : КНЕУ, 2017. № 1. С. 124-136.

12. Історія українського права: навч. посіб. / За ред. проф. О.О. Шевченка. Київ : Олан, 2001. 214 c.

13. Козинець О. Судоустрій $і$ судочинство за Судебниками 1497 ma 1550 рр. Підприємництво, господарство $і$ право. Kü̈в, 2010. № 3. C. 35-38.

14. Сторчилова Н.В. Коррупциия в органах внутренних дел и ее предупреждение: диссертащия кандидата юридических наук: 12.00.08/ Всерос. науч.-исслед. ин-т МВД РФ. Москва, 2010. $194 \mathrm{c}$.

15. Номоков П.В. Уголовно-правовая характеристика получения взятки : диссертаиия кандидата юридических наук: 12.00.08. Иркутск, 2005. 187 с.

16. Кабанов П.А. Коррупиия и взяточничество в России: исторические, криминологические и уголовно-правовые аспекты. Нижнекамск : ИПЦ «Гузель», 1995. 172 c.

17. Михайленко О.P. Прокуратура України : підручник / за ред. О.Р. Михайленко. Київ : Юрінком Iнтер, 2005. 296 с.

18. Скипский Г.А., Михеева С.М. Коррупция в полищии как фактор крушения Российской империи. Вестник Уральского юридического института МВД России. Екатеринбург, 2018. С. 66-70.

19. Семенова Н.Л. Донесение Министра внутренних дел А.А.Закревского "O недостатках губернского правления 1831 г.». Международный научный журнал «Инновационная наука». Еліста, 2017. № 01-2. C.128-129.

20. Говоров И.В. Проблема коррупциии в российской полищии на рубеже ХІХ-XX вв. Новейшая история России. Санкт-Петербург, 2011. № 2. С. 122-140.

21. Зайончковский П.А. Правительственный аппарат самодержавной России в ХІХ в. / за ред. П.А. Зайончковського. Москва: Мысль, 1978. С. 156.

22. Молчанов В.Б. Корупиія як соиіальний чинник добробуту імперської адміністрациї у підросійській Україні в XIX - на початку XX cm.: збірник наукових праць. Kü̈в, 2008. Bun. 14. C. 247-267. 


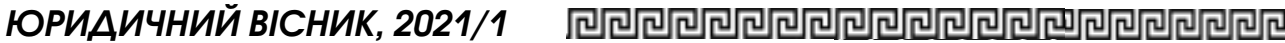

23. Говоров И. Указ. Соч. С. 130.

24. Вергун C.I. Корупиія у діяльності транспортної жандармерії залізнищь України (друга половина ХІХ - початок XX cm.). Проблеми історії України XIX поч. ХХ ст.: збірник наукових праць. Київ, 2017. Bun. 26. C. 32.

25. Протидія хабарниитву у бюджетній сфері підрозділами Державної служби з економічною злочинністю: наукпракт. посіб. / за заг. ред. О.М. Джужі. Київ, 2011. 185 c.

26. Цитряк В.Я. Хабарництво: історико-правові аспекти соціального явища та протидії йому в Україні. Актуальні проблеми держави і права. Одеса, 2009. Bun. 48. C. 241-245.

27. Кримінальний кодекс УРСР 1927 р. Київ : Держполітвидав, 1950. 168 с.

28. Гусєва В.П. Відповідальність за вчинення корупиіниих правопорушень учасників кримінального процесу УРСР у 20-х роках XX століття. Боротьба з організованою злочинністю $i$ корупцією (теорія і практика): наук.-практ. журн. Київ, 2013. Bun. № 2(30). C. 103-104.

29. Михеева о. Украинская милииия 1920-х годов: материаль «киевского deлa». URL: http://argumentua.com/ stati / ukrainskaya-militsiya-1920-khgodov-materialy-kievskogo-dela (Jama звернення: 11.02.2021).

30. Палибин Н.В. Записки советского адвоката, 20-е - 30-е годы. Paris : YMCAPRESS, 1988. C. 53-54.

31.Яковенко С.Б. Генезис та ровзитко корупції: історичний аспект. Науково-інформаційний вісник Академії національної безпеки. Київ, 2015. Bun. 3-4 (7-8). C. 58-71.

32. Указ Президиума Верховного Совета СССР «Об уголовной ответственности за хищение государственного и общественного имущества» от 04.06.1947 2. URL: https:// www.1000dokumente.de/index.html?c= dokument_ru\&dokument $=0012$ eig\&object $=$ context\&l=ru $\quad($ dama $\quad$ звернення: 20.01.2021).

33. Сопілко I.M. Корупиія в Україні як спадщина радянського державного управління. Юридичний вісник. Повітряне $i$ космічне право. Київ, 2018. № 2. С. 89-94.

34. Боровой А., Ильина О. Коррупиия в СССР: 7 громких уголовных дел. URL: https: / / pasmi.ru/archive/95250/_(dama звернення: 10.02.2021). 